\title{
Similarities Between R.M. Schindler House and Descriptions of Traditional Japanese Architecture
}

\author{
Jose Manuel Almodovar Melendo*1, Juan Ramon Jimenez Verdejo ${ }^{2}$ \\ and Ismael Dominguez Sanchez de la Blanca ${ }^{3}$
}

\author{
${ }^{1}$ Professor, School of Architecture, University of Seville, Spain \\ ${ }^{2}$ Associate Professor, Graduate School of Environmental Planning, University of Shiga Prefecture, Japan \\ ${ }^{3}$ Ph.D. in Architecture, School of Architecture, University of Seville, Spain
}

\begin{abstract}
Kings Road House has become an icon of early modern architecture. This innovative house, described by Schindler as "a cooperative dwelling for two young couples", was considered by Reyner Banham to be a totally new beginning. Although many papers devoted to the house have been published, no research has been conducted into its relationship with the interpreted characteristics of Japanese architecture or the sources from which Schindler may have obtained information about Japan in 1921 without ever having traveled to the country. In this paper, the authors hope to clarify the matter and shed new light on some of the elements of Japanese architecture found in Schindler's House, including the aspects of sun and light control. This was done through research into original documents in archives in California and with the help of contemporary simulation tools, duly tested by means of on-site measurements. The results show clear similarities between key concepts of Schindler House and descriptions of Japanese architecture. Some of these concepts have been considered essential elements of Schindler architecture and were subsequently reproduced in other houses in California.
\end{abstract}

Keywords: R.M. Schindler; Kings Road House; Japanese architecture; Southern California Modernism; lighting design

\section{Introduction}

Japonism was of great interest in the cultural circles of Vienna, the city where R.M Schindler qualified as an architect, and where he was to come into contact with Adolf Loos and Otto Wagner. Many grand masters of the Modern Movement who greatly admired Japanese architecture, such as Hermann Muthesius, Walter Gropius, Bruno Taut and Frank Lloyd Wright, visited Japan.

Although Schindler had never visited Japan, when he built his first house in Los Angeles in 1921, he already knew about Japanese architecture as a result of his collaboration with Frank Lloyd Wright, whose relation with the Orient has been extensively studied (Nute, 1993).

Schindler collaborated closely with Wright in the design and construction of the Imperial Hotel in Tokyo, among other commissions in Japan. Through him, Schindler met Japanese architects who were invited to Taliesin to collaborate on the Imperial Hotel. In

*Contact Author: Jose Manuel Almodovar Melendo, Professor, School of Architecture, University of Seville, Avda. Reina Mercedes 2, 41001 Seville, Spain Tel: +34-954-28-32-20 Fax: +34-954-55-69-72 E-mail: jmalmodovar@us.es

(Received April 12, 2013 ; accepted November 11, 2013) this way, Schindler met Arata Endo, the only architect to share credits with Wright, and Goichi Fujikura, a recent Cornell University graduate (Fig.1.). Arata Endo was hired as chief draftsman for the Imperial Hotel Project and during his one-year stay in Taliesin (1917-1918) he worked with the team responsible for transforming Wright's sketches into working plans for the Imperial Hotel and into drawings for five Japanese residences and a theatre. Schindler and Arata Endo maintained a long friendship. More than ten years after their first meeting in Taliesin, Endo wrote to Schindler from Japan, recommending him to Takehiro Okami (Schindler Collection, 11-f.109).

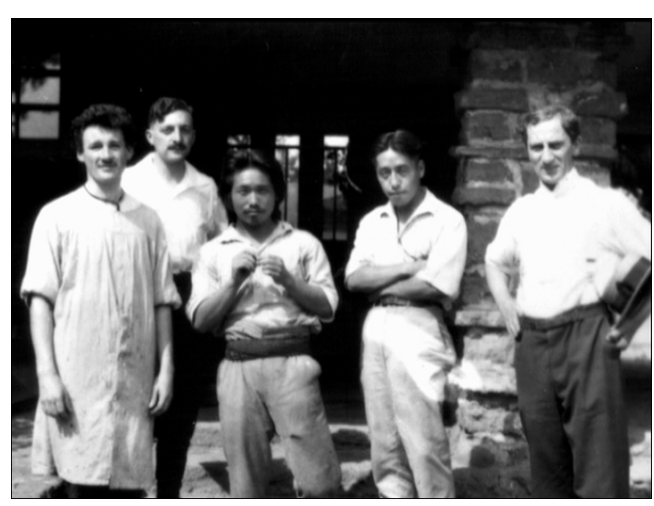

Fig.1. In the Center, from Left to Right: R.M. Schindler, Arata Endo and Goichi Fujikura in Taliesin 
In 1920, Schindler moved to Los Angeles to supervise the construction of Hollyhock House while Wright was in Tokyo. The initial proposal was that Schindler would visit Japan afterwards, as stated in the telegram he sent to Wright in 1921, saying "everything settled cable instructions Japan trip Schindler" (Inventory FLLW, Box 2-f.7, 31062). During this time of constant correspondence with Wright, Schindler designed and constructed Kings Road House.

Wright returned to Los Angeles in January 1923, bringing Kameki and Nobu Tsuchuira, who would work with him in Los Angeles and Taliesin for two years. In this time, they formed part of Schindler's circle of friends, attending celebrations at Kings Road House. After the Tsuchiuras returned to Japan, they regularly corresponded with Schindler.

The Tsuchiuras also had a close relationship with Richard Neutra, who they met for the first time in Taliesin in 1924. In 1925, Richard and Dione Neutra moved into Schindler House, where they lived until 1930. That year, Neutra made a 3-week trip to Japan, which was made possible by his friendship with the Tsuchiuras and Kokusai Kenchiku's sponsorship. In 1921, Neutra had already shown an interest in traveling to Japan. Schindler, as a way of helping his old university friend from Austria, wrote a letter to Wright in which he commented, "I received a letter from Mr. Neutra, who is very willing to come to Japan" (Inventory FLLW, Box 2-f.6, 31155a).

Another of Schindler's sources of information about Japanese Architecture could have been the book Japanese Homes and their Surroundings, written in 1886 by the American scientist, Edward Morse. This book also could have provided Wright with comprehensive knowledge of Japanese architecture before his first trip to Japan in 1905. In this regard, Nute observes that "several of the positive characteristics of the Japanese dwelling highlighted by Morse [have] apparently become central elements in the Prairie House" (Nute, 1993, 44).

It is possible that Wright met Morse through Fenollosa, who was the cousin of his first employer, Joseph Lyman. In the Columbian Exposition of Chicago in 1893, they were official judges of pottery and fine arts, respectively. In this Exposition, Japan constructed the celebrated pavilion known as Ho-oDen (Phoenix Palace). Morse recommended Ernest Fenollosa as a professor of Philosophy and Political Economics at the Tokyo Imperial University and the two men formed part of a circle of friends who were connected to the Tokyo Imperial University as well as the Boston Museum of Fine Arts.

The authors have attempted, without success, to ascertain whether Schindler had a copy of Morse's book. However, given his close relationship with Wright and the role played by Morse in the dissemination of Japanese aesthetic ideals in the United States, the authors can assume that he knew the book.
One person who did leave written evidence of his interest in Morse's work was Bruno Taut. In his famous book Houses and people of Japan, Taut reproduces some of his illustrations. However, referring to Morse's approach to Japanese architecture, he states that "there were no important errors [...]. Yet while treating the same subject, I had not judged it necessary to discuss the same things as Morse" (Taut, 1958, 256).

When Schindler first published his house in T-square (1932), more than 10 years after its construction, he made no allusion to Japanese architecture. He defined it as a 'cooperative dwelling for two young couples' and compared it to a 'camp site'. Although Schindler's work has been comprehensively studied (Sheine, 2001; March and Sheine, 1995; Gebhard, 1997; Park, 2012), in particular Kings Road House (Smith, 2010), no study has been made of the relationships between the spatial features of Schindler House and interpreted characteristics of Japanese architecture. The authors shall discuss this relevant aspect of the innovative Schindler House, that was considered by Reyner Banham to be a construction that transcends "anything done by anybody (including himself) before Le Corbusier's Villa Savoye of 1930" (Banham, 1971).

\section{Compositional Scheme}

In relation to the scheme of the house, Schindler states in the article published in T-square that "the ordinary residential arrangement providing rooms for specialized purposes has been abandoned. Instead, each person receives a large private studio, each couple a common entrance hall and bath. Open porches on the roof are used for sleeping. An enclosed patio for each couple, with an out-of-door fireplace, serves the purposes of an ordinary living room. The form of the house divides the garden into several such private rooms" (Schindler, 1932).

The house plan, defined by Schindler as "a cooperative dwelling for two couples", is very innovative. He bases the design on L-shaped structures that delimit the outdoor living spaces that function as a prolongation of the interior spaces. By using foliage barriers and integrating sunken gardens, he not only limits access from the exterior, but also consolidates the privacy of these spaces (Fig.2.).

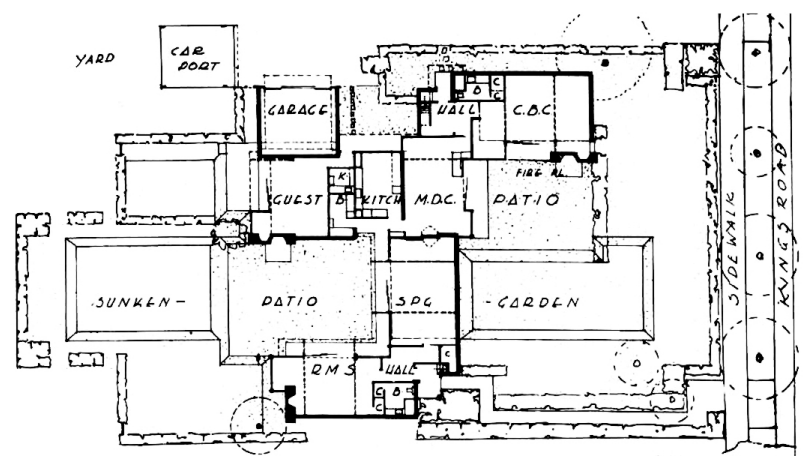

Fig.2. Ground Floor Plan 
Consequently, there is no direct connection between the public space and Schindler House. This is a typical characteristic of Japanese houses, as described by Morse so meticulously in his book. Bruno Taut also notes that in Japan "neighborliness has therefore in a way two different faces: one looking towards the inside, the other to the outside [...]. The intimate life of the house and the family [is] protected from the neighbors by high fences" (Taut, 1958, 222).

As in Japanese architecture, Schindler bases his proposal on spatial continuity between adjoining multifunctional spaces, which in turn establishes a close interior-exterior connection. The spaces are articulated in such a way that "all rooms will become part of an organic unit, instead of being small separate boxes with peep-holes" (Schindler, 1926a). Nevertheless, in this singular "cooperative dwelling", each spatial unit is designed for one individual in such a way that he has a private room to provide a background for his or her life.

Moreover, the spatial units or "study rooms" are closed to the exterior with thick concrete walls and are open to interior patios with lighter, permeable elements (Fig.3.). Schindler explains the solution adopted and that "the shape of the rooms, their relation to the patios and the alternating roof levels, create an entirely new spatial interlocking between the interior and the garden" (Schindler, 1932).
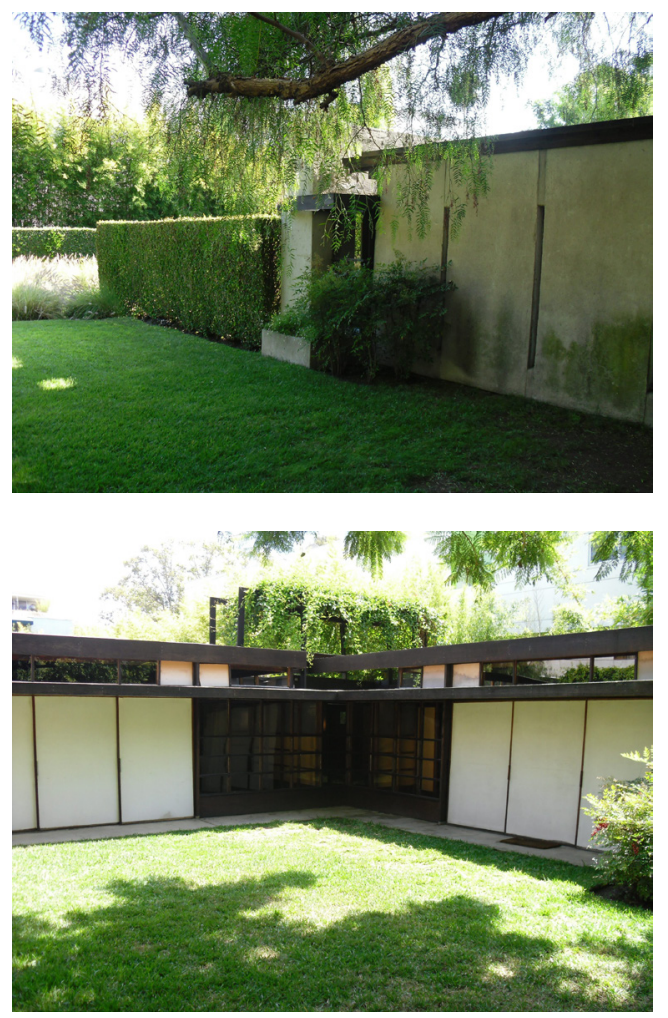

Fig.3. Above: The Exterior Face is Closed with Concrete Walls and Foliage Barriers. Below: The Interior is Opened to the Patios

Although Schindler uses innovative materials and construction techniques (for example, solid tilt-up concrete for the exterior walls), similarly to Morse's description of Japanese architecture, he designs the rooms as multifunctional spaces where the essential everyday elements are stored away in large closets. Schindler places these large storage spaces in the shared elements of each couple; bathrooms and beneath the stairs of each entrance hall. The latter means of storage is very common in Japanese dwellings, having been illustrated previously by Morse in his book and afterward mentioned in Bruno Taut's Houses and people of Japan.

This compositional scheme, which resembles traditional Japanese homes, had nothing in common with the typical American houses of that time, so described by Wright as "boxes beside or inside boxes, called rooms. All boxes inside a complicated outside boxing. Each domestic function was properly box to box. I could see little sense in this inhibition [...] except for the privacy of bedrooms on the upper floor. They were perhaps all right as sleeping boxes" (Nute, 1993). As a result, Wright designed sleeping porches in Barnsdall House, a project in which Schindler collaborated while he was away in Tokyo and also in the Terrace Houses (1920). Sleeping porches for each couple were also designed in Schindler House.

\section{Constructive System}

Morse elaborately describes the Japanese post-andbeam construction system, in which the exterior and interior divisions (shôji and fusuma respectively) are non-supporting screens aligned with the structure.

According to Morse's description, the interior space is modulated by beams which also serve as the frames of the non-structural mobile divisions. Morse calls these beams kamoi, although their correct name is nageshi. The kamoi is a flat lintel with grooves in which the sliding screens run, situated immediately below the nageshi. This construction system allows the spatial continuity and exterior connection mentioned above simply by removing the divisions.

Schindler implements a composite construction system that is clearly similar to that described by Morse. In the description of his project in T-Square, he comments that "all partitions and patio walls are nonsupporting screens composed of a wooden skeleton filled in with glass or with removable canvas panels". In each studio room there are two crossing beams which, like the nageshi, modulate the space and serve as frames for additional moveable partitions.

These spatial concepts could also have been present in Wright's work. According to Nute, one of the principal characteristics of the Prairie House is "an idea very similar to Morse's characterization of the Japanese home as essentially one large space divided only by non-structural screens" (Nute, 1993).

In Schindler House, the divisions are aligned to the structure in such a way that the interior spaces are conditioned by the nature of the structure. This aspect 
is accentuated by the use of canvas panels, which are translucent panels like the Japanese shoji that limit the structure (Fig.4.). According to Judith Sheine, this characteristic differs from Le Corbusier's open-floor plan system and from Richard Neutra's treatment of spaces, which tends more to the International Style (Sheine, 2001).
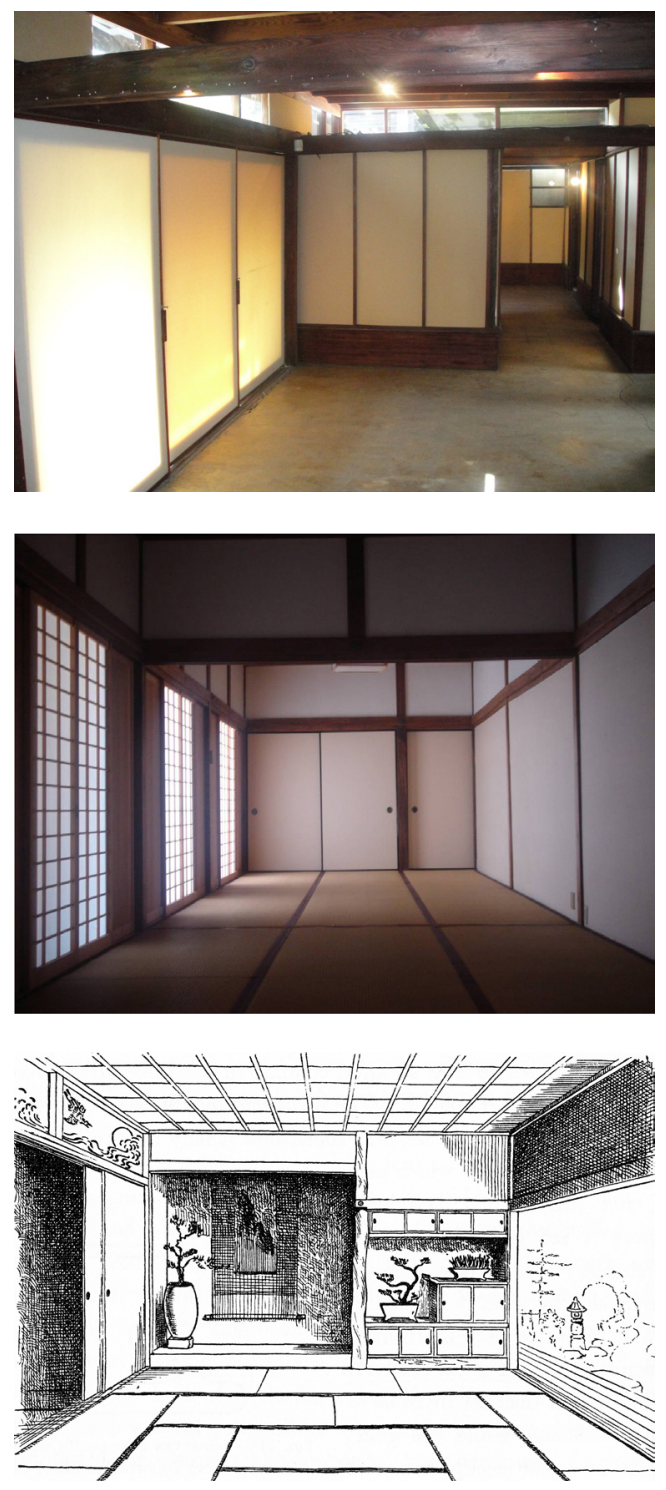

Fig.4. The Interior Space is Modulated by the Structure Above: Schindler House. Center: Traditional Japanese House. Below: Edward Morse's Illustration, p.138

\section{Materials}

In Japan, the structure is designed as a modulator of the interior spaces. It is therefore an essential aesthetic component of the house. With respect to this, Bruno Taut comments that "the construction, meaning the supporting posts, is thus an essential part of the decoration in the Japanese room" (Taut, 1958, 33). In fact, the structure is covered with boards and hidden only in the auxiliary elements of less importance.

Schindler clearly incorporates a similar Japanese concept in his use of materials, though he does not mention it explicitly. In this regard, he says he uses "a simple weave of a few structural materials which retain their natural color and texture throughout" (Schindler, 1932). In Schindler House, he uses a combination of innovative technology and new materials such as canvas panels and reinforced concrete, as used by Gill in the construction of the nearby Dodge House (today demolished). The interior divisions are of cardboard and sequoia wood. All of these materials are left exposed in their natural state, reapplying the Japanesearchitectural ideal that he shares with Wright: "the ornament should be of the surface not on the surface" (Inventory FLLW, Box 1-f.1, 31057). In other words, he uses new materials and innovative construction techniques, while keeping in mind the Japanese concepts of the use of materials.

To a certain extent, it could be said that Schindler attempts to reproduce the Japanese aesthetic concept of wabi (absence of decoration as a result of the quest for the essence) and sabi (related to the passing of time) through modern techniques. According to Bruno Taut, in Japan, natural wood represents "the beginning and the end, youth and old age. Beautiful wood that is old is not beautiful simply because it is beautiful, but also because it has gone through a long journey, or we could say, a vital experience" (Taut, 1958, 91). Following this Japanese concept, Schindler states that the wood needed to be only "wire-brushed to accentuate the grain" (Schindler, 1932).

Consequently, in the Kings Road House, all superfluous ornaments are eliminated to find the "vacuum", and thus "leave it to the sensibility to apprehend what it has enshrouded" (Taut, 1958, 89). In this regard, Raymond comments that in Japanese space "it could seem that the wish to try to eliminate the inessential, to clarify the space, to look for the essence in all, eventually, in the silence created, one hears the voice of the form, the substance and the space" (Raymond, 1972).

\section{Schindler Proportional System}

Like other modern architects, R.M. Schindler wanted to combine construction systems with industrialized production through standardization. This long-desired ideal in modern architecture has always existed in the Japanese architectural tradition. In this regard, Walter Gropius sent a postcard to Le Corbusier from Kyoto in 1954, informing him that "all that we have been fighting for has its parallel in old Japanese culture [...]. The Japanese house is the best and most modern I know of and truly prefabricated".

Moreover, Richard Neutra, on his return from Japan after having lived in Kings Road for five years, commented that "the rich and the poor, the urban wealthy and the peasant, all had the same standard of dimensions, from tatami floor mats, sliding door panels, to tansu, built-in drawer sets. Detailing and finishing were as simple and normalized as they were 
superbly neat. I had been striving for all that, and I was no longer alone" (Hines, 2006, 114).

The system of proportions used in traditional Japanese architecture is called kiwari and is based on the distance between pillars, ken. This dimension differs slightly depending on the period and the region. The dimensions of the rest of the elements of the dwelling are related to this measurement.

Morse does not expressly mention the kiwari or the unit of reference, the ken, in his book. With regard to the proportions used in Japan, he comments that "the dimensions of the mats from one end of the Empire to the other are approximately three feet wide and six feet long" (Morse, 1961, 26) and, of the movable partitions dividing the rooms, he says that they "are nearly six feet in height, and about three feet in width. The framework of a house, [...] is arranged with special reference to the sliding screens, as well as to the number of mats which are to cover the floor" (Morse, 1961, 110).

That is to say, the dimensions of the mats are the same as those of the sliding screens and, obviously, the height of the screens ( 6 feet) determines the dimensions of the nageshi. Schindler does not use mats in his house and, therefore, they are not used as the modulator of the floor plan. However, they condition the frame-work of the house to the height of the sliding screens that he used as the basis of the proportion system that he developed for Los Angeles. To do this, he sizes the pillars to have the same height as the sliding screens, placing beams upon them to serve as the lintel of the windows and the doors. These beams, which could be equivalent to the Japanese nageshi, give horizontal continuity to the space and allow flexibility in varying the height of the ceiling above according to the spatial necessities.

However, Schindler increases the height at which the beams are situated from $6^{\prime}(1.82 \mathrm{~m})$ to $6^{\prime} 8^{\prime \prime}(2.03 \mathrm{~m})$ to adapt the Japanese space to western needs. Morse comments that "the height of the beam itself from the floor, a nearly constant factor, is always lower than our doorways" (Morse, 1961, 168). It should be borne in mind that the Japanese traditionally sit on the floor, on the mats. Consequently, the problem of adapting this space to western style, which uses chairs, had to be resolved.

As a result, the dimension system established by Schindler is modulated from a base distance of 4 feet and fractions of this, the most common being $1 / 2,1 / 3$ and $1 / 4$. He establishes a height of $12 / 3$ units $\left(6^{\prime} 8^{\prime \prime}\right.$ or $2.03 \mathrm{~m})$ for the beams and door height, and a standard room height of 2 units ( $8^{\prime}$ or $2.43 \mathrm{~m}$ ).

Schindler applied his proportional system for the first time in Kings Road House and later in other projects. Schindler's proportion system, published in Reference Frames in Space, is considered by Lionel March as "one of the most important articles on proportion written in the twentieth century" (Sheine, 2001).

Referring to the standardization of architecture,
Wright pointed out that "the Oriental artist sees in everything the pattern and the western artist, values" (James, 1968). On one of his trips to Japan, he acknowledged, "I found this ancient Japanese dwelling to be a perfect example of the modern standardizing I had myself been working with" (James, 1968). Later, in the Usonian Houses, he also used this idea of designing from a simple geometrical unit.

\section{Daylighting}

Morse comments in his book that houses in Japan remain fairly closed towards the exterior, but open to interior gardens through translucent moveable panels known as shôji. In this way, "as the room, when closed, receives its light through the shôji, the windows have in most cases lost their functional character and have become modified into ornamental features" (Morse, 1961, 174). Therefore, windows were often designed with an ornamental sense to have visual contact with a previously planned landscape. Morse comments, as an example, that in a Japanese inn he visited, from the dining area, an attractive landscape was viewed through a small window. However, behind the window there was a minuscule garden of only three feet in width that "had been utilized solely for the benefit of the room within" (Morse, 1961, 284).

In Kings Road House, Schindler proposes a scheme in which "each room has a concrete wall for back, and a garden front with a large opening fitted with sliding doors" (Schindler, 1932). In this way, "the traditional small pane of the times of primitive technique has been supplanted by the large sheet of plate glass, removing the bars between us and the out-of-doors" (Schindler, 1926b). Schindler designs gardens at a level lower than that of the terrain which contribute to the privatization of the patios and, furthermore, they clearly have a landscaping function. They act as a backdrop to the view seen from the bedrooms looking towards the patios. In this regard, there are similarities to the shakkei (borrowed landscape) technique used in Japan. It should be underlined that, in Japanese dwellings, the differences between levels facilitate the contemplation of the garden by a person seated on the tatami. Specifically, the engawa (a kind of veranda situated between the bedrooms and the garden) is situated at an intermediate height between the ground and the floor of the dwelling.

In contrast, as in Morse's description, the back wall has very small windows and its main function is probably ornamental since according to Schindler, "light must be made to permeate the whole space and not remain a glaring spot area produced by a conventional small window opening in a dark wall (Schindler, 1952).

Towards the garden, he places translucent canvas panels which subtly divide adjoining space forms without separating them. Schindler justifies this solution stating that "translighting is the exact opposite 
of the art-glass window of the past, the effect of which was predicated on a background of the somber walls of the cathedral" (Schindler, 1952).

The shôji in Japan, similarly to the canvas panels, "does not allow more than a filtered reflection of the light projected by the garden to penetrate" (Tanizaki, 1977). As its transmittance is much lower than that of glass, they significantly reduce the interior illumination. According to on-site measurements that the authors have taken, the transmittance of the shoji ranges from 0.5 to 0.6 , depending on the time and weather, while that of the canvas panels is even lower, in no case reaching 0.3 . Possibly to compensate this low transmittance, Schindler alternates the large sliding canvas panels with glass surfaces.

The wide overhangs that protect the shoji also help to darken the rooms. In Japan, according to Tanizaki, the first structure to be built is a "roof as a sunshade that determines a perimeter on the floor that is protected from the sun. In this shadow the house is built" (Tanizaki, 1977). The resultant play of shadows was brilliantly described in his book In Praise of Shadows.

As in Japan, Schindler also protects the spaces that open onto the patios by means of an overhanging eave, carried by two cantilever beams crossing the rooms. However, he introduces a clever innovation to achieve illumination levels that are more acceptable to western standards. He designs clerestory windows between ceiling levels, present throughout the house (Fig.5.). As a result, "the shape of the rooms, their relation to the patios and the alternating roof levels, create an entirely new spatial interlocking between the interior and the garden" (Schindler, 1932).

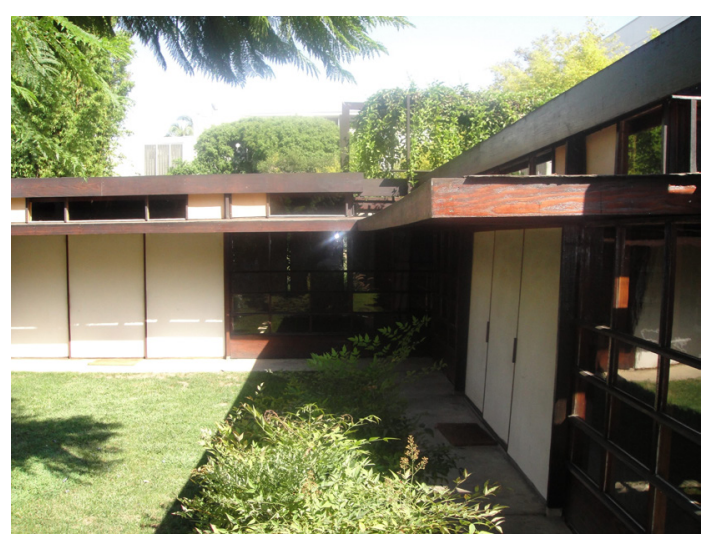

Fig.5. Clerestory Window over a Large Overhang

The authors wish to underline that the clerestory window is not a traditional element of Japanese architecture. In our opinion, it is an intelligent innovation introduced by Schindler to increase illumination levels and to adapt traditional Japanese space to Western needs. As it shall be seen in the following section, other architects, such as Taut and Wright, surprisingly reproduced years later a very similar scheme.
On the other hand, this solution favors ventilation of the interior space. Probably the clerestory was originally openable, as Schindler states that he wanted to "provide a cooling air current right under the roof" (Schindler, 1932). Moreover, in the article that Schindler wrote about ventilation in the series Care of the Body, he said that "proper constant ventilation necessitates exhaust openings to the outside near the ceiling and near the floor, whereas the pure air should be allowed to enter at the height of its level of density" (Schindler, 1926c).

The authors prepared a computer simulation to analyze the effect of the innovative section proposed by Schindler in the interior daylighting field. The authors used a procedure based on the calculation of luminous radiative transfers that the authors have applied in other cases (Almodovar, 2008). The simulation was conducted in the winter and summer solstices under both overcast and clear skies. Real measurements were also taken on-site using a luxmeter.

The results show that the luminous field is extraordinarily uniform and the illumination level approximates to the required standards under clear and sunny sky conditions, frequent in Los Angeles. The wide overhanging eaves, which act as light-shelves, have an important effect on the increase in natural lighting. The authors took as a hypothesis that they were originally covered with white gravel, which the authors assume to have a reflection coefficient of 0.8 . This is what is indicated in Schindler's project plans and he also stated that "the gravel roof used too is the most durable of all modern protectors against the rain" (Smith, 2010).

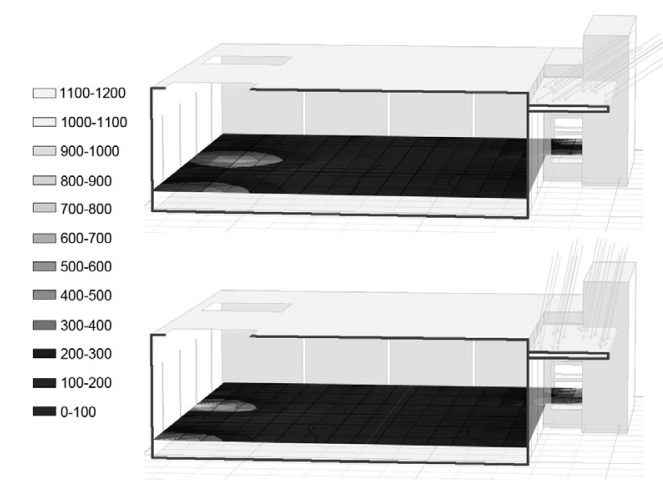

Fig.6. Daylighting Distribution for Clear Sky Plus Sun, Values in Lux. Above: December 12:00 HST. Below: June 12:00 HST

\section{Other Experiences}

Wright was aware of the significant effect produced by the eaves on indoor illumination. Regarding the solution designed for the Imperial Hotel, he comments that "overhangs had a double value: shelter and preservation for the walls of the house, as well as this diffusion of reflected light for the upper story through the "light screens" (James, 1968). 
In Taliesin West, he experimented with translucent pivoted panels which, depending on their position, filter the light or act as light-shelves that reflect the light into the interior (Fig.7.). It is evident that Wright had an interest in exploring the illumination possibilities of translucent screens, traditionally used in Japan. He also stated that "not one inch of glass is going into Taliesin West" (Pfeiffer, 2008).

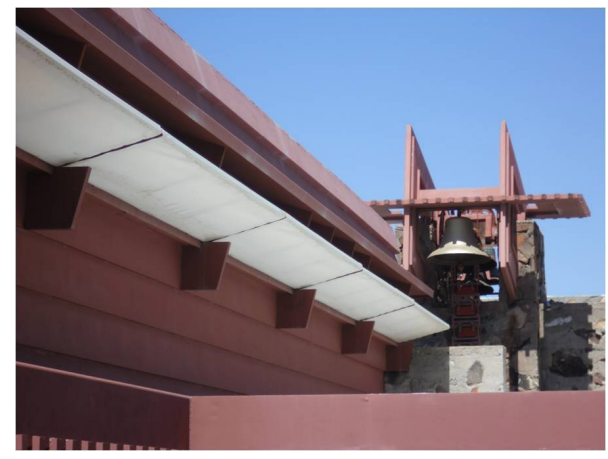

Fig.7. Translucent Panels Used as Light-Shelves, Taliesin West
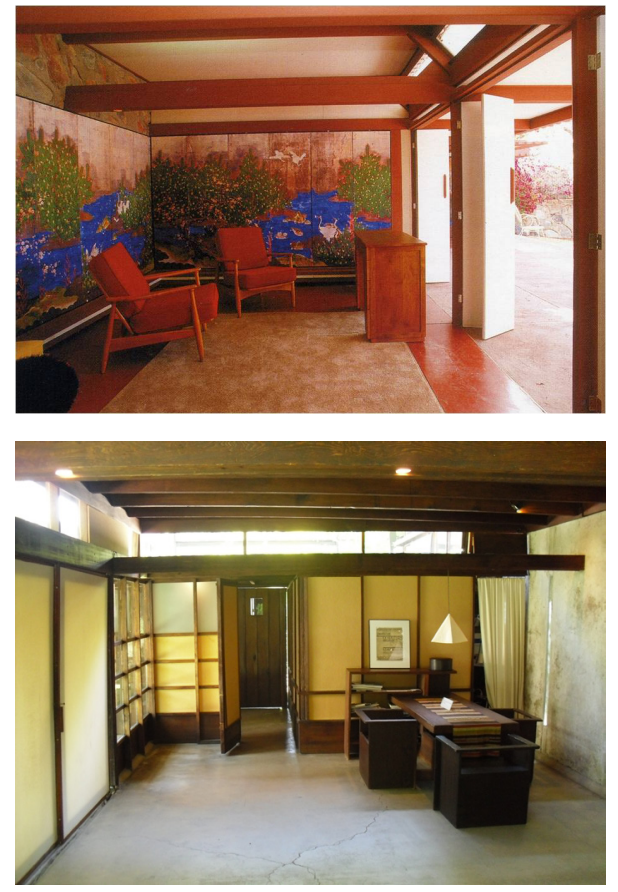

Fig.8. Above: Wright's Private Living Quarters, West Taliesin. Below: Schindler's Studio, Kings Road House

In his private chambers in Taliesin West, he reproduces a composite scheme that generates a daylighting field and interior atmosphere that is very similar to that of the Schindler House (Fig.8.). It is possible that Wright knew Kings Road House, because in 1923, while Schindler was working for him, he lived only six blocks away for six months. Moreover, Wright published an article in the same magazine, T-Square, in which Kings Road House was published for the first time.

In Japan, more than a decade after the construction of Kings Road House, Bruno Taut also experimented with elements of the Japanese tradition, especially the aspects of sun, light and ventilation (Cabeza, 2007).

Taut was interested in Schindler's work. In his book Bauen, der neue Wohnbau (1927), he published Schindler's Pueblo Ribera Court project. In Modern Architecture, he commented: "In America there is hardly anything to be seen of a modern movement in the European sense, with the exception of certain quite sporadic, isolated examples, grouped around pupils of Wright, or individual attempts in California (Schindler and Neutra in Los Angeles)" (Taut, 1929).

Taut could have gathered information about Schindler House through Antonin Raymond, another of Wright's pupils. Raymond traveled to Japan to collaborate in the Imperial Hotel project in Tokyo. Afterwards, he undertook long and interesting work looking for a synthesis between Japanese architecture and modern architecture (Gloaguen, 2006).

In 1910, Antonin Raymond and his wife, the artist Noemi Pernessin, met Schindler at Wright's Oak Park studio and in Taliesin, where they worked together on drawings of Barnsdall House. Noemi served as a broker of Japanese art objects for clients, including Schindler's wife, Pauline Gibling, with whom she later corresponded (Schindler Collection, 12-f.275). In 1932, the Raymonds made a trip to the USA, during which they visited Schindler House and met Wright in Taliesin (Helfrich et al., 2006). Two years later, on their return to Japan, the Raymonds met Bruno Taut on several occasions.

Bruno Taut, in his effort to incorporate climatic elements of Japanese architecture into modern architecture, also made a proposal that recalls the projected section by Schindler in Kings Road House. This can be seen in the sketch he designed in 1936 for the Okura Villa in Tokyo (Fig.9.).

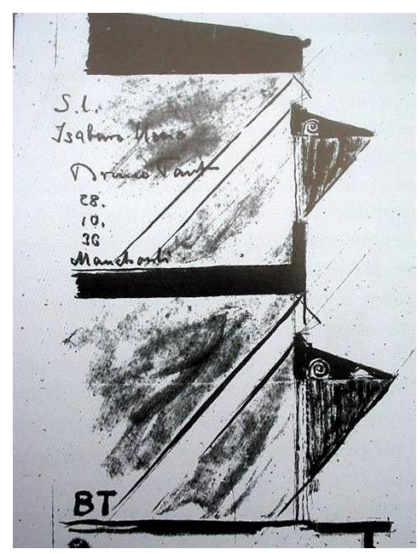

Fig.9. Sketch for a Section of the Okura Villa in Tokyo, B. Taut

With this solution, he attempted to overcome the lighting limitations of traditional Japanese architecture to meet the demands of modern life, while maintaining its environmental qualities. Taut justifies this proposal saying that, "it cannot be terribly difficult to find an arrangement for simultaneously shading roofs and 
providing light for the rooms inside. You need only lay out a low row of windows above the fore-roof. Light can be easily regulated by means of blinds" (Taut, 1958).

\section{Conclusion}

R.M. Schindler could have learned about Japanese architecture as a result of his collaboration with Frank Lloyd Wright and contact with Japanese architects who worked on the project for the Imperial Hotel in Tokyo.

There are similarities between key aspects of Schindler House and the descriptions of traditional Japanese architecture given by Edward Morse in his book Japanese Homes and their Surroundings.

Specifically, Schindler generated continuity between adjoining multifunctional spaces instead of rooms inside rooms with particular functions. The rooms are closed to the outside and open to the courtyards through large opening walls. In this way, he avoids establishing a direct relationship with public space and closely associates the rooms with the patios and gardens, which are given a landscaping treatment. In addition, a post-and-beam construction system is used and divisions are aligned to the structure. Schindler establishes a low horizontal datum by means of beams, similar to the Japanese nageshi, acting as a lintel for the doors and large opening walls. The height of these beams is used as a base unit for the proportional system designed for California. From this measurement, varying ceiling heights were established. He uses materials in their natural state and eliminates all superfluous ornamentation. On the exterior, he places translucent screens that can be removed, as can the shôji in Japan, and also allows the possibility of using removable panels aligned with the beams that cross the rooms, in the style of the fusuma. Consequently, spaces are conditioned by the structure, achieving great spatial fluidity.

Moreover, Schindler projects a large overhang similar to the noki used in Japan. However, above it he designed a clerestory which increases illumination to achieve a level more suited to the contemporary lifestyle. He thereby creates a new interior-exterior connection that allows users to enjoy the temperate climate of California.

In our opinion, Schindler realized the potential of Japanese architecture in the contemporary scene and made a very intelligent effort to revitalize traditional concepts. To some extent, other modern architects who were contemporaries of Schindler, such as Bruno Taut and Frank Lloyd Wright, were also involved in the task of creating a modern idiom for climatic elements of the Japanese house.

Some of the concepts discussed above have been considered as essential points of Schindler architecture and can be found in the rest of his projects, such as continuity between adjoining spaces, large openings in walls, large overhangs, clerestory windows, low horizontal datum and varying ceiling heights.

\section{Acknowledgements}

The authors should like to thank Judith Sheine and Robert L. Sweeney for the discussions which helped us develop our ideas and for allowing our work inside Schindler House.

The authors express our special appreciation to Katheryn Smith for her helpful comments during our research at the Getty Research Institute and also Jocelyn Gibbs, curator of the ADC, for making it possible for us to consult the Archives of the Schindler Collection.

\section{References}

1) Almodóvar, J.M. et al. (2008). Nineteen thirties architecture for tropical countries: Le Corbusier's brise-Soleil at the Ministry of Education in Rio de Janeiro. Journal of Asian Architecture and Building Engineering, 7(1): pp.9-14.

2) Banham, R. (1971) The Master Builders: 5. The Sunday Times Magazine (London), p.26.

3) Cabeza, J.M. et al. (2007) The Japanese experience of environmental architecture through the works of Bruno Taut and Antonin Raymond. Journal of Asian Architecture and Building Engineering, 6(1): pp.33-40.

4) Gloaguen, Y. (2006) The "Architect" in Antonin Raymond's way of thinking. Journal of Asian Architecture and Building Engineering, 5(2): pp.245-251.

5) Helfrich, K.G. and Whitaker, W. (2006) Crafting a modern world: the architecture and design of Antonin and Noémi Raymond. New York: Princeton Architectural Press.

6) Inventory of the Frank Lloyd Wright correspondence with R.M. Schindler, 1914-1929, bulk 1918-1922. The Getty Research Institute, Los Angeles.

7) James, G. (1968) Frank Lloyd Wright's Imperial Hotel. New York: Dover Publications, Inc.

8) March, L. and Sheine, J. (1995) R.M. Schindler: composition and construction. Academy Press.

9) Morse, E. (1961) Japanese homes and their surroundings. New York: Dover Publications.

10) Nute, K. (1993) Frank Lloyd Wright and Japan: the role of traditional Japanese art and architecture in the work of Frank Lloyd Wright. London: Chapman and Hall.

11) Park, J.H. (2012) The interplay of modular idea and symmetry in Rudolf M. Schindler's housing. Journal of Asian Architecture and Building Engineering, 11(2): pp.335-342.

12) Pfeiffer, B.B. (2008) Frank Lloyd Wright's encounters with the desert. Quarterly, 16 (1), pp.4-23.

13) Raymond, A. (1972) Antonin Raymond: an Autobiography. Rutland: Charles E. Tuttle Company.

14) Schindler Collection, Architectural Drawing Collection (ADC). University Art Museum, University of California, Santa Barbara.

15) Schindler, R.M. (1926) Shelter or Playground (Care of the Body). Los Angeles Times, Sunday magazine section, 2. May, pp.26-27.

16) Schindler, R.M. (1926) About Lighting ("Care of the Body). Los Angeles Times, Sunday magazine section, 11. April, pp.30-31.

17) Schindler, R.M. (1926) Ventilation (Care of the Body). Los Angeles Times, Sunday magazine section, 14. March, pp.25-26.

18) Schindler, R.M. (1932) A Cooperation Dwelling. T-Square, Band 2, pp. 20-21.

19) Schindler, R.M. (1952) Visual Technique (unpublished), ADC.

20) Sheine, J. (2001) R. M. Schindler. Phaidon Press Limited.

21) Smith, K. (2010) Schindler House. Hennessey \& Ingalls.

22) Tanizaki, J. (1977) In Praise of Shadows. Leete's Island.

23) Taut, B. (1929) Modern Architecture. 1 ed. London: A. \& C. Boni.

24) Taut, B. (1958) Houses and people of Japan. 2nd ed. Tokyo: Sanseido Co.

25) Hines, T.S. (2006) Richard Neutra and the Search for Modern Architecture. 4th ed. Rizzoli. 